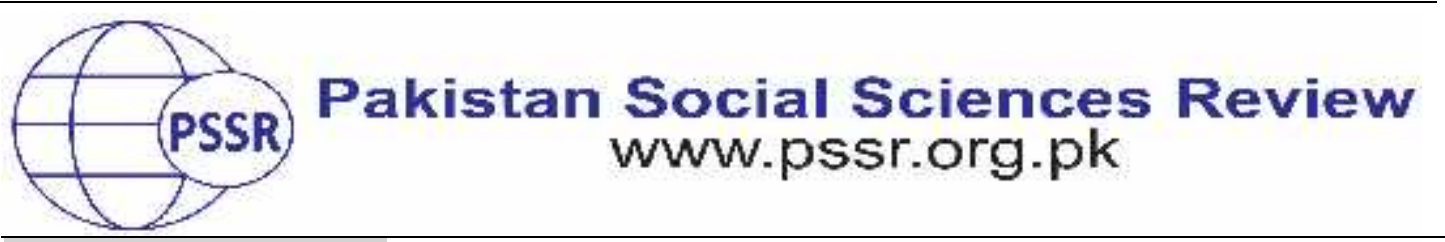

RESEARCH PAPER

\title{
Parenting Styles and Academic Self-Concept of Students
}

\author{
Hafsa Noreen*1 Mushtaq Ahmad ${ }^{2}$ Abida Parveen ${ }^{3}$
}

1. Lecturer, Department of Education, Pioneer Science College Bhalwal, Sargodha, Punjab, Pakistan

2. Assistant Professor, Department of Education, University of Sargodha, Punjab, Pakistan

3. Lecturer, Department of Education, The University of Lahore, Sargodha campus, Punjab, Pakistan

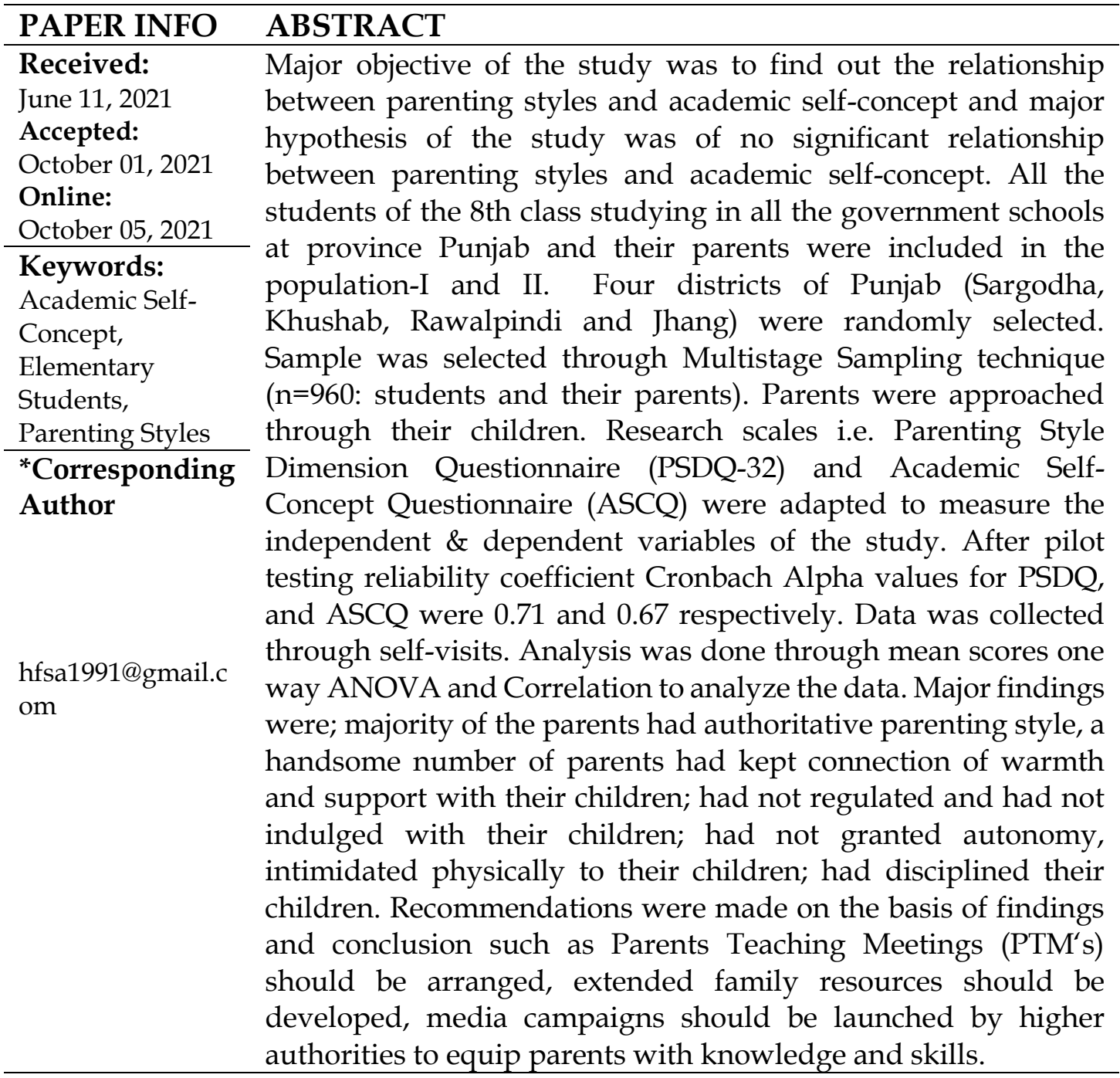

Introduction 
It's agreed upon notion that parent's home is the first institution for children whereas parents build their foundation by playing the role of mentor and similarly the children act like trainees. Children are greatly influenced by parents positively or negatively because they spend majority of their time with them. Therefore, parents affect attitudes, behaviors, thoughts, and values of the children life. Parents also have highly prominent part in the development of their children and mold their off springs through inspiration to live a successful life in this world (Ooi, Choi \& Husna, 2015).

Parenting can be described in two modules likewise, parenting responsiveness and demandingness (Ooi, Choi, \& Rabeatul Husna, 2015). Parenting styles are categorized on the basis of levels of parenting demandingness i.e. command, control, adulthood demands etc. and responsiveness i.e. participation, acceptance and warmth etc. Further, parenting styles have portrayed as a three dimensional structure which is; authoritarian (controlling style), authoritative (empowering) and permissive (allowing) parenting styles (Heberle et al., 2015).

As first learning institute is home and parents are a reference point and an important example for their children (van der Horst \& Sleddens, 2017). Parents are role model for building of their children character and development of personality because they are the only inspirational source during their children development process. In short parents play vital role in building character, personality and morals their children (Miranda et al. 2016).

It is concluded from the discussion of Vera-Rios, (2018) that parenting styles has four key dimensions i.e. clarity of communication, demands for maturity, control, and nurturance. A parenting style is like emotional atmosphere of parent-child relationship and this atmosphere is in the form how parents communicate, interact, regulate, maintain, supervise, and guide their children (Muhammad, Hoshiar \& Sadiq, 2018). Connecting parental styles with the family, Dornbusch, Philip, Ritter, Leiderman, Roberts, \& Fraleigh, (1987) suggested three parenting styles i.e. Authoritarian Parenting Style, Authoritative Parenting Style \& Permissive Parenting Style. Each is discussed below in brief.

\section{Authoritarian Parenting Style}

Parents practicing authoritarian style insist that their children follow parenting directions, use a restrictive, punitive style and strict disciplinarians. Though such parents are caring and have good child-parent communication with children but they are also extremely demanding (Baumrind, 1991).Parents of authoritarian parenting style exercises their full authority and instead the children they make all decision (Muhammad, Hoshiar \& Sadiq, 2018).

\section{Authoritative Parenting Style}

Parents with authoritative style nurture their children with permission to develop their own opinion and belief, provide them with moderate level of control and courage to be responsive. Moreover, parents of this style involve their offspring 
in debates and arguments because the main responsibility lies with the parents (Ooi, Choi \& Rabeatul Husna, 2015).

\section{Permissive Parenting Style}

Parents of permissive style allow their children with all freedom in decision making. On the other hand, children of permissive parents show little initiative and are immature and anxious, (Zupancic, Podlesek, \& Kavcic, 2014). Similarly, parents with permissive parenting style have low demand but expect high responsiveness. To sum up, parents of permissive style spoil their children as they do not use controlling, penalties, and put limits for the children.

Usually, parents play a pivotal role in the developmental process of their children. Further, it is found that parenting styles provide important elements which serves for the development of academic self-concept of their children (DeDonno \& Fagan, 2015).

\section{Academic Self-Concept}

Academic self-concept characterizes attitude and feelings in relation to the student's own intellectual abilities compared to other students at school (Jee \& Shahlan, 2017). Within academic self-concept, we differentiate between cognitive representations such as self-concept represented at the level of description e.g. "I am wise" and affective representations like self-concept represented at the level of emotions e.g. "I am proud of myself".(Ooi, Choi \& Rabeatul Husna, 2015).

\section{Relationship of Parenting Styles and Academic Self-Concept}

Niaraki and Rahimi (2017) proposed a major effect of parenting style on selfconcept of child. More specifically, the child's academic self-concept is positively related with warmth of the parents. Conversely, it is negatively associated with parental punishment, over-protection and rejection (Lin, 2016).

Similarly, according to (Hernandez, 2015), Parenting styles were extremely major augur of academic self-concept. So, the outcomes of the above studies support the idea that parenting styles influence academic self-concept of students.

Specifically, this study was aimed to explore the effect of parenting styles on academic self-concept of students (at elementary level) because the researcher observed that little attention is given to the contribution of parenting styles and students' academic self-concept. Therefore, the researcher thought that examining the effect of parenting styles on academic self-concept of students at elementary level is of paramount significance and pivotal.

\section{Hypothesis}


Ho: There is no significant relationship between parenting styles and academic selfconcept of the students of $8^{\text {th }}$ class". 


\section{Material and Methods}

The present study was descriptive and data were collected through survey techniques.

Population and sample: All the districts of Punjab were included in the target population of the study. There were two types of accessible populations' populationI (all students of class $8^{\text {th }}$ ) \& population-II (All the parents of 8th class students).Sample of 960 students was selected through Multistage Random Sampling technique. The steps of Multistage Random Sampling technique are as follows:

i. $\quad$ Four districts (Sargodha, Khushab Jhang and Rawalpindi) were selected on convenient basis. Thus, the desired sample size was about $10 \%$ of the population.

ii. Simple Random Sampling was used to select the schools from each district. Then 4 schools (2 Girls schools and 2 Boys schools) were selected randomly from each district.

iii. Sixty (60) students were selected from each selected school.

\section{Instrumentation}

Parenting Styles and dimensions Questionnaire (PSDQ-32) and Liu \& Wang's Academic Self-Concept Questionnaire (ASCQ) were adapted with permission of the scale developers to measure and analyze parents' Parenting Styles and the academic self-Concept of students. Both scales were 5 point Likert scale.

\section{Data Collection and Data Analysis}

Researcher distributed 960 copies of instruments as per sample and out of which 960 copies completely filled were received back. Response rate was 100\%. Data were analyzed using descriptive and inferential statistics; frequencies, percentage, mean score, standard deviation and One-Way ANOVA.

\section{Results and Discussion}

Table 1

Gender wise distribution of parents and students

\begin{tabular}{cccccc}
\hline & Parents & & \multicolumn{3}{c}{ Students } \\
\hline Gender & & Percentage & Gender & & Percentage \\
\hline Mother & 685 & $71 \%$ & Male & 480 & $50 \%$ \\
\hline Father & 275 & $29 \%$ & Female & 480 & $50 \%$ \\
\hline Total & 960 & $100 \%$ & Total & 960 & $100 \%$ \\
\hline
\end{tabular}

Table 1 represents the distribution of parents in the sample with respect to gender. There were $71 \%$ (685) mothers and 29\% (275) fathers in the sample of 960 
parents of elementary level students. So, it indicates that mothers were more than the fathers in the sample.

Moreover, there were 50\% (480) male students and 50\% (480) female students in the sample of 960 students at elementary level. It indicates that male and female students were included equally in sample.

Table 2

Parenting style wise categorization of parents

\begin{tabular}{ccc}
\hline & Frequency & Percent \\
\hline Authoritative Parenting Style & 589 & $61.4 \%$ \\
\hline Authoritarian Parenting Style & 245 & $25.5 \%$ \\
\hline Permissive Parenting Style & 126 & $13.1 \%$ \\
\hline Total & 960 & 100.0
\end{tabular}

Table 2 illustrates that $61 \%$ parents (589) had authoritative parenting style whereas $25.5 \%$ (245) parents' parenting style was authoritarian and remaining $13 \%$ parents' parenting style was permissive. It depicts that majority of parents parenting style is authoritative.

Table 3

Parenting styles of mothers and fathers

\begin{tabular}{ccccc}
\hline \multirow{2}{*}{ Parents } & $\begin{array}{c}\text { Authoritative } \\
\text { Parenting Style }\end{array}$ & $\begin{array}{c}\text { Authoritarian } \\
\text { Parenting Style }\end{array}$ & $\begin{array}{c}\text { Permissive } \\
\text { Parenting Style }\end{array}$ & \multirow{2}{*}{ Total } \\
\hline \multirow{2}{*}{ Mother } & 423 & 180 & 82 & 685 \\
& $61.75 \%$ & $26.27 \%$ & $12 \%$ & 275 \\
\multirow{2}{*}{ Father } & 166 & 65 & 44 & \\
& $60.36 \%$ & $23.63 \%$ & $16 \%$ & 960 \\
\multirow{2}{*}{ Total } & 589 & 245 & 126 & $100.0 \%$ \\
\hline
\end{tabular}

Table 3 shows that among mothers $62 \%$ had authoritative parenting style, $26 \%$ had authoritarian parenting style whereas only $12 \%$ had permissive parenting style. Similarly, among fathers, $63.36 \%$ had authoritative parenting style; $23.63 \%$ had authoritarian parenting style and only $16 \%$ had permissive parenting style. Majority of the mothers and fathers had authoritative parenting style.

Table 4

Qualification wise Parenting styles

\begin{tabular}{|c|c|c|c|c|}
\hline \multirow{2}{*}{$\begin{array}{c}\text { Parents' } \\
\text { Qualification }\end{array}$} & \multicolumn{3}{|c|}{ Finalized Parenting Style } & \multirow[b]{2}{*}{ Total } \\
\hline & $\begin{array}{l}\text { Authoritative } \\
\text { Parenting Style }\end{array}$ & $\begin{array}{l}\text { Authoritarian } \\
\text { Parenting Style }\end{array}$ & $\begin{array}{c}\text { Permissive } \\
\text { Parenting Style }\end{array}$ & \\
\hline \multirow{2}{*}{ Primary } & 115 & 59 & 24 & 198 \\
\hline & $58.0 \%$ & $29.8 \%$ & $12.12 \%$ & $20.6 \%$ \\
\hline \multirow{2}{*}{ Middle } & 13 & 1 & 4 & 18 \\
\hline & $72.22 \%$ & $5.56 \%$ & $22.22 \%$ & $1.9 \%$ \\
\hline
\end{tabular}




\begin{tabular}{ccccc}
\hline \multirow{2}{*}{ Matriculation } & 132 & 49 & 37 & 218 \\
\hline \multirow{2}{*}{ FA / FSc } & $60.55 \%$ & $22.48 \%$ & $16.97 \%$ & $22.7 \%$ \\
\cline { 2 - 5 } & 62 & 26 & 10 & 98 \\
\hline \multirow{2}{*}{ BA or MA } & $63.27 \%$ & $26.53 \%$ & $10.20 \%$ & $10.2 \%$ \\
\cline { 2 - 5 } & 63 & 32 & 11 & 106 \\
\hline \multirow{2}{*}{ Other } & $59.42 \%$ & $30.18 \%$ & $10.40 \%$ & $11.0 \%$ \\
\cline { 2 - 5 } & 204 & 78 & 40 & 322 \\
\hline \multirow{2}{*}{ Total } & $63.36 \%$ & $24.22 \%$ & $12.42 \%$ & $33.5 \%$ \\
\cline { 2 - 5 } & 589 & 245 & 126 & 960 \\
\hline
\end{tabular}

Table 4 shows that $20.6 \%$ parents' qualification was primary and among them $58 \%$ had authoritative parenting style and $29.8 \%$ had authoritarian parenting style whereas only $12.12 \%$ had parenting style. Majority of the parents $(72.2 \%)$ wit middle level education also had authoritative parenting style. Similarly majority of the parents $(61 \%)$ with matric (secondary) level education also had authoritative parenting style and $22.5 \%$ had authoritarian parenting style. Majority of parents with intermediate level education (FA / FSc) had authoritative parenting style (63.27\%) and authoritarian parenting style (26.53\%). Likewise parents with graduate or master level education (BA / MA) had authoritative parenting style $(59.42 \%)$ and authoritarian parenting style (30.18\%).

A weak trend appeared that with better education parenting style changes from authoritative to authoritarian style.

Table 5

Factor wise analysis of Authoritative Parenting Style

\begin{tabular}{|c|c|c|c|c|c|c|c|c|c|c|}
\hline S\# & Construct & $\begin{array}{c}\text { Always } \\
\mathrm{f}(\%)\end{array}$ & $\begin{array}{l}\text { Often } \\
\text { f (\%) }\end{array}$ & $\begin{array}{l}\mathrm{A}+\mathrm{O} \\
\mathrm{f}(\%) \\
\end{array}$ & $\begin{array}{c}\text { Now \& } \\
\text { Then } \\
\text { f }(\%)\end{array}$ & $\begin{array}{l}\text { Rare } \\
\mathrm{f}(\%)\end{array}$ & $\begin{array}{c}\text { Never } \mathrm{f} \\
(\%)\end{array}$ & $\begin{array}{l}\mathrm{R}+\mathrm{N} \\
\mathrm{f}(\%)\end{array}$ & M & SD \\
\hline 1 & $\begin{array}{l}\text { Connection } \\
\text { Dimension } \\
\text { (Warmth \& } \\
\text { Support) }\end{array}$ & $22.14 \%$ & $27.4 \%$ & $\begin{array}{c}49.6 \\
\%\end{array}$ & $20.64 \%$ & $20.06 \%$ & $9.68 \%$ & $30.28 \%$ & 2.91 & 1.24 \\
\hline 2 & $\begin{array}{c}\text { Regulation } \\
\text { Dimension } \\
\text { (Reasoning / } \\
\text { Induction) } \\
\end{array}$ & $16.46 \%$ & $21.38 \%$ & $\begin{array}{c}37.84 \\
\%\end{array}$ & $20.32 \%$ & $30.02 \%$ & $11.8 \%$ & $41.84 \%$ & 3.28 & 1.15 \\
\hline 3 & $\begin{array}{c}\text { Autonomy } \\
\text { Granting } \\
\text { Dimension } \\
\text { (Democratic } \\
\text { Participation) }\end{array}$ & $17.0 \%$ & $18.9 \%$ & $\begin{array}{c}36.74 \\
\%\end{array}$ & $21.04 \%$ & $27.3 \%$ & $15.6 \%$ & $42.94 \%$ & 3.11 & 1.21 \\
\hline
\end{tabular}

The overall trend in the factor connection Dimension (warmth and support) was that $50 \%$ parents with mean score 2.91 , always or often keep connection of warmth and support with their children whereas $20.6 \%$ keep connection warmth and 
support just now and then while 30\% parents rare or never keep connection with their children.

The overall trend in the factor Regulation Dimension (Reasoning/Induction) is that $42 \%$ parents with mean score 3.28 , rarely or never regulate their children with reasoning whereas $20 \%$ parents regulate now and then while $38 \%$ parents always or often regulate their children with reasoning.

The overall trend in the factor autonomy granting dimension (Democratic Participation) is that $43 \%$ parents with mean score 3.11 , rarely or never grant autonomy of participation or democracy to their children whereas $21 \%$ parents now and then grant autonomy while $37 \%$ parents always or often grant autonomy to their children. Data analysis shows the parents with authoritative parenting style keep moderate connection of warmth and support with their children; do not use reasoning to regulate their children and never grant autonomy of participation or democratic right to their children.

Table 6

Factor wise analysis of Authoritarian Parenting Style

\begin{tabular}{|c|c|c|c|c|c|c|c|c|c|c|}
\hline S\# & Construct & $\begin{array}{c}\text { Always } \\
\text { f (\%) }\end{array}$ & $\begin{array}{l}\text { Often } \\
\mathrm{f}(\%)\end{array}$ & $\begin{array}{l}A+O \\
f(\%)\end{array}$ & $\begin{array}{c}\text { Now \& } \\
\text { Then } \mathrm{f}(\%)\end{array}$ & $\begin{array}{l}\text { Rare } \\
\mathrm{f}(\%)\end{array}$ & $\begin{array}{c}\text { Never } \\
\text { f }(\%)\end{array}$ & $\begin{array}{l}R+N \\
f(\%)\end{array}$ & M & SD \\
\hline 1 & $\begin{array}{c}\text { Physical } \\
\text { Coercion } \\
\text { Dimension } \\
\text { Factor }\end{array}$ & $30.7 \%$ & $\begin{array}{c}22.32 \\
\%\end{array}$ & $53.02 \%$ & $21.77 \%$ & $\begin{array}{c}14.17 \\
\%\end{array}$ & $11.05 \%$ & 25.22 & 2.52 & 1.28 \\
\hline 2 & $\begin{array}{c}\text { Verbal } \\
\text { Hostility } \\
\text { Dimension } \\
\text { Factor }\end{array}$ & $20.35 \%$ & $28.3 \%$ & $48.3 \%$ & $23.3 \%$ & $18.6 \%$ & $12.4 \%$ & $31 \%$ & 3.08 & 1.3 \\
\hline 3 & $\begin{array}{c}\text { Non- } \\
\text { Reasoning/ } \\
\text { Punitive } \\
\text { Dimension } \\
\text { Factor }\end{array}$ & $22.97 \%$ & $25.0 \%$ & $48.0 \%$ & $22.32 \%$ & $14.9 \%$ & $14.72 \%$ & $29.6 \%$ & 2.51 & 1.27 \\
\hline
\end{tabular}

The overall trend in the factor physical coercion dimension is that $53 \%$ parents with mean score 2.52 and SD 1.28, always or often physically intimidate their children to whereas $22 \%$ parents intimidate now and then while $25 \%$ parents rarely or never physically intimidate their children.

The overall trend in the factor verbal hostility dimension is that $48 \%$ parents with mean score 3.08 and SD 1.3, always or often were verbally hostile to their children whereas $23 \%$ parents now and then use verbal hostility while $31 \%$ parents were rarely or never verbally hostile to their children.

The overall trend in the factor non-reasoning/punitive dimension is that $48 \%$ parents with mean score 2.51, always or often use punitive discipline to their children whereas $22 \%$ parents were punitive now and then while $30 \%$ parents rarely or never were punitive to their children. 
Table 7

Factor wise analysis of Permissive Parenting Style

\begin{tabular}{ccccccccccc}
\hline S\# & Construct & $\begin{array}{c}\text { Always } \\
\mathrm{f}(\%)\end{array}$ & $\begin{array}{c}\text { Often } \\
\mathrm{f}(\%)\end{array}$ & $\begin{array}{c}\mathrm{A}+\mathrm{O} \\
\mathrm{f}(\%)\end{array}$ & $\begin{array}{c}\text { Now \& } \\
\text { Then } \mathrm{f}(\%)\end{array}$ & $\begin{array}{c}\text { Rare } \\
\mathrm{f}(\%)\end{array}$ & $\begin{array}{c}\text { Never } \\
\mathrm{f}(\%)\end{array}$ & $\begin{array}{c}\mathrm{R}+\mathrm{N} \\
\mathrm{f}(\%)\end{array}$ & $\mathrm{M}$ & $\mathrm{SD}$ \\
\hline 1 & $\begin{array}{c}\text { Indulgent } \\
\text { Dimension }\end{array}$ & $16.4 \%$ & $\begin{array}{c}18.76 \\
\%\end{array}$ & $35.16 \%$ & $22.16 \%$ & $\begin{array}{c}27.1 \\
\%\end{array}$ & $15.5 \%$ & $42.6 \%$ & 3.03 & 1.27 \\
\hline
\end{tabular}

The overall trend in the factor indulgent dimension is that $43 \%$ parents with mean score 3.03 , rarely or never indulge with their children activities whereas $22 \%$ parents were now and then indulge while $35 \%$ parents always or often got indulge to their children activities.

Table 8

Analysis of student's responses about Academic Self-Concept

\begin{tabular}{ccccccccccc}
\hline S\# & Construct & $\begin{array}{c}\text { Always } \\
\mathrm{f}(\%)\end{array}$ & $\begin{array}{c}\text { Often } \\
\mathrm{f}(\%)\end{array}$ & $\begin{array}{c}\mathrm{A}+\mathrm{O} \\
\mathrm{f}(\%)\end{array}$ & $\begin{array}{c}\text { Now \& Then } \\
\mathrm{f}(\%)\end{array}$ & $\begin{array}{c}\text { Rare } \\
\mathrm{f}(\%)\end{array}$ & $\begin{array}{c}\text { Never } \\
\mathrm{f}(\%)\end{array}$ & $\begin{array}{c}\text { R+N } \\
\mathrm{f}(\%)\end{array}$ & $\mathrm{M}$ & $\mathrm{SD}$ \\
\hline 1 & $\begin{array}{c}\text { Academic } \\
\text { Confidence }\end{array}$ & $26.3 \%$ & $28.5 \%$ & $54.8 \%$ & $9.66 \%$ & $20.49 \%$ & $\begin{array}{c}15.02 \\
\%\end{array}$ & $35.51 \%$ & 2.13 & .939 \\
\hline 2 & $\begin{array}{c}\text { Academic } \\
\text { Efforts }\end{array}$ & $27.62 \%$ & $28.44 \%$ & $56.06 \%$ & $15.11 \%$ & $15.3 \%$ & $\begin{array}{c}13.51 \\
\%\end{array}$ & $28.81 \%$ & 2.77 & .982 \\
\hline
\end{tabular}

The overall trend in the factor academic confidence was that $55 \%$ students with mean score 2.13, were academically confident during their studies whereas $36 \%$ students were not academically confident during their studies while only $10 \%$ students were somewhat confident.

The overall trend in the factor academic effect was that $56 \%$ students with mean score 2.77, put academic efforts during their studies whereas $29 \%$ students were not putting academic efforts during their studies while $15 \%$ students were putting academic efforts to some extent.

Table 9

One way ANOVA among Parenting Styles w.r.t Academic Self-Concept

\begin{tabular}{cccccc}
\hline & $\begin{array}{c}\text { Sum of } \\
\text { Squares }\end{array}$ & Mean Square & F & df & Sig. \\
\hline Between Groups & 56875.433 & 28437.716 & 108.327 & 3 & 0.000 \\
\hline Within Groups & 251228.641 & 262.517 & & 957 & \\
\hline Total & 308104.074 & & & 960 & \\
\hline
\end{tabular}

Table 9 portrays that a significant difference was found among the mean score of academic self-concept of the students at elementary level with respect to parenting style as indicated by $\mathrm{F}$ - value $=960$ with $\mathrm{df}=108.327$ and $\mathrm{p}$-value $=0.000<0.05$. Additionally, to see the further difference, post hoc test was applied and presented in the table below. 
Table 10

Post hoc test for the difference of students' Academic Self-Concept with respect to Parenting Styles

\begin{tabular}{ccccc}
\hline (I)Parenting Style & (J) Parenting Styl & Mean Difference (I-J) & Std. Error & Sig. \\
\hline $\begin{array}{c}\text { Authoritative Parenting } \\
\text { Style }\end{array}$ & Authoritarian Parenting Style & $7.851^{*}$ & 1.232 & .000 \\
\cline { 2 - 5 } & Permissive Parenting Style & $22.853^{*}$ & 1.590 & .000 \\
\hline $\begin{array}{c}\text { Authoritarian Parenting } \\
\text { style }\end{array}$ & Permissive Parenting Style & $15.001^{*}$ & 1.776 & .000 \\
\hline
\end{tabular}

Table 10 illustrates the results of Post hoc test Tukey's HSD that the students whose parents have authoritative Parenting style have better academic self-concept than the students whose parents have authoritarian parenting style as mean difference 7.851 was significant and p-value $0.000<0.05$. Similarly the students whose parents have authoritative parenting style have better academic self-concept than the students whose parents have permissive parenting style as mean difference 22.853 was significant and p-value $0.000<0.05$ whereas students whose parents have authoritarian parenting style have better academic self-concept than the students whose parents have permissive parenting style as mean difference 15.001 was significant and p-value $0.000<0.05$

Table 11

Relationship between Parenting Style and Academic Self-concept of students

\begin{tabular}{|c|c|c|c|}
\hline Categories & $\mathrm{N}$ & $\mathrm{R}$ & Sig. p-value \\
\hline $\begin{array}{c}\text { Parenting Styles } \\
\text { Academic self-concent of students }\end{array}$ & 960 & 0.771 & .003 \\
\hline
\end{tabular}

Table 11 reflects that a strong and positive and significant relationship exist between parenting styles and academic self-concept of students as indicated by $\mathrm{r}=$ $.771, \mathrm{n}=960, p=.003<0.05$.

\section{Discussion}

There exited a significant relationship between parenting style and academic self-concept of students. The level of academic self-concept of students whose parents have authoritative parenting style is better than the authoritarian and permissive parenting style of the parents as Sofie Kuppens., \& Eva Ceulemans., (2019) highlighted many reasons for the association between authoritative parents and students' academic self-concept. A strong and positive correlation was found between parenting style and academic self-concept of the students as cited in Fox (2017) discovered that children of authoritative parents have positive association with their academic self-concept.

\section{Conclusion}

Conclusion drawn from data analysis are that majority of the parents both mothers and fathers had authoritative parenting style and to some extent better education parenting style changes from authoritative to authoritarian style. 
Parents with authoritative parenting style keep moderate connection of warmth and support with their children; do not use reasoning to regulate their children and never grant autonomy of participation or democratic right to their children. On the other hand parents with authoritarian parenting style often physically intimidate their children, were often verbally hostile and often use punitive discipline to their children whereas parents of permissive parenting style rarely or never indulge with their children activities

In the construct of academic self-concept more students were academically confident and putting academic efforts

A strong and positive and significant relationship was found between parenting styles and academic self-concept of students. Moreover, students whose parents have authoritarian parenting style have better academic self-concept than the students whose parents have authoritarian and permissive parenting style.

\section{Recommendations}

In parents teachers meeting (PTM's), teachers may try to reduce the communication gap between teachers and parents and guide the parents to adopt suitable parenting style when dealing their children for their better academic selfconcept. 


\section{References}

Beato, A. Pereira, A. I. Barros, L. \& Muris, P. (2016). The relationship between different parenting typologies in fathers and mothers and children's anxiety. Journal of Child and Family Studies, 25, 1691-1701.

DeDonno, M. A. \& Fagan, J. F. (2013). The Influence of Family Attributes on College Students' Academic Self-concept. North American Journal of Psychology, 15(1), 49-62.

Heberle, A. E. Briggs-Gowan, M. J. \& Carter, A. S. (2015). A person-oriented approach to identifying parenting styles in mothers of early school-age children. Infant and Child Development, 24, 130-156.

Hernandez, A. A. (2015). The relationship among the nurturance and monitoring dimensions of parenting, academic self-concept, and acculturation in the academic achievement of Latino college students. (Doctoral dissertation, University Of Southern California, 2009). Dissertation Abstracts International, 70, 2889A.

Jee, P. \& Shahlan, S. (2017). Gaya Keibubapaan Dengan Tingkahlaku Devian Dalam Kalangan Remaja. Prosiding STEd 2017 (pp. 230 - 237). Bangi: University Kebangsaan Malaysia

Lin, H. (2016). A study of correlation of parental rearing patterns with behavior problems and self-concepts in primary school underachievers. Chinese Journal of Clinical Psychology, 12(1), 50-52.

Miranda, M. C. Affuso, G. Esposito, C. \& Bacchini, D. (2016). Parental acceptancerejection and adolescent maladjustment: mothers' and fathers' combined roles. Journal of Child and Family Studies, 25(4), 1352-1362. Journal of Education and Social Sciences, Vol. 7, Issue 1, (June) ISSN 2289-1552 2017191

Muhammad, Hoshiar \& Sadiq. (2018). Parenting styles and their impact on children's academic self-concept, behavioral problems and executive functions, Durham theses, Durham University. Available at Durham E-Theses Online: http://etheses.dur.ac.uk/12548/

Niaraki, F. R. \& Rahimi, H. (2017). The impact of authoritative, permissive and authoritarian behavior of parents on self-concept, psychological health and life quality. European Online Journal of Natural and Social Sciences,2(1), 78-85.

Ooi, S. H. Choi, S. L. \& Rabeatul Husna, A. R. (2015). An Analysis on the Relationship between Parenting Styles and Self-Esteem of Students of a University in Malaysia: A Case Study. Mediterranean Journal of Social Sciences, 300 - 3310. 
Sofie Kuppens. \& Eva Ceulemans. (2019). Parenting Styles: A Closer Look at a WellKnown Concept. Journal of Child and Family Studies, 28, 168-181. https://doi.org/10.1007/s10826-018-1242-x

Van der Horst, K. \& Sleddens, E. F. (2017). Parenting styles, feeding styles and foodrelated parenting practices in relation to toddlers' eating styles: a cluster-analytic approach. PloS One, 12(5), e0178149.

Vera-Rios, J. (2018). The Relationship Between Parenting Styles and Conduct Disorder in Hispanic Families. Walden Dissertations and Doctoral Studies Collection. Retrieved from https://scholarworks.waldenu.edu/dissertations.

Viktor, B. \& Fox, R. A. (2017). An empirically derived classification of parenting practices. The Journal of Genetic Psychology, 160, 343-356

Zupancic, M. Podlesek, A. \& Kavcic, T. (2014). Parental child care practices of Slovenian preschoolers' mothers and fathers: The family environment questionnaire. Horizons of Psychology, 13(3), 7-26. 